ISMC 2021

$16^{\text {th }}$ International Strategic Management Conference

\title{
CORPORATE LIFE CYCLE AND FINANCIAL PERFORMANCE IN TERMS OF EMERGING MARKETS
}

\author{
Lucia Michalkova (a)* \\ *Corresponding author \\ (a) University of Zilina, Faculty of Operation and Economics of Transport and Communications, Univerzitna 1, 010 \\ 26 Zilina, Slovakia, lucia.michalkova@fpedas.uniza.sk
}

\begin{abstract}
Financial performance is one of the key aspects in creating a business strategy. The complexity of this variable and its impact on the risk of bankruptcy or further development of companies has proven to be key in the current economic shock as well as in past economic crises. This study aims to examine and evaluate the impact of the corporate life cycle on financial performance represented by return on assets.in emerging economies. The variables Leverage and Size expressed as operating profit and Age of the company were also evaluated for a comprehensive assessment of the impact of financial performance. Two-way ANOVA was applied, where the factors were the life cycle according to the Dickinson model and the Country factor with two alternatives - the Czech Republic and Slovakia. The results of the study indicate that return on assets, leverage and operating profit of companies in the surveyed economies develops in an inverted U-shape, where the highest profitability and operating profit are achieved by companies in the growth stage, while the lowest leverage and thus credit risk is in the shake-out stage. The life cycle of an average company is compressed, which corresponds to the sectoral structure of the examined economies focused on industrial sectors. This implies that business strategy should take into account differences in performance over the life cycle, and a thorough life cycle analysis should be the basis for creating a predictable business strategy.
\end{abstract}

2357-1330 @ 2021 Published by European Publisher.

Keywords: Financial performance, corporate life cycle, profitability, earnings, risk 


\section{Introduction}

The financial performance of companies is influenced by many quantitative and qualitative factors. From the point of view of internal company factors, these are mainly liquidity, indebtedness, turnover of accounts receivable turnover or profit margin. High indebtedness, low liquidity and low profitability can result in an increase in the risk of financial distress or corporate default (Kliestik, Nica et al., 2020, Riley et al., 2021). These quantitative factors, together with macroeconomic factors such as inflation, GDP or the unemployment rate representing the economic cycle, are important variables in the process of creating a company's financial strategy.

In addition to the economic cycle, the corporate life cycle is another key factor in corporate strategy, as the various stages require diverse managerial decisions (Metzker \& Zvarikova, 2021). Although corporate life cycle is important to strategic management, this factor is very little explored in terms of financial management and the impact on financial performance. There are several studies dealing with the business life cycle and its impact on financial management, such as Hussain et al. (2020), Gulec and Karacaer (2017), or Tian et al. (2015). In the field of Central European emerging economies, this research is represented by only a few studies such as Konecny and Zinecker (2016), Pinkova and Kaminkova (2012) or Michalkova (2021). These studies largely address the impact of a company's life cycle on profitability and earnings management in developing countries, but have several shortcomings. First of all, other factors of financial performance (such as profitability, leverage or liquidity) in relation to the corporate life cycle are not sufficiently examined. Second, these studies do not take into account the specifics of emerging economies, such as the predominance of small and medium-sized unlisted enterprises. This points to a significant gap in life cycle impact research on financial management in emerging economies.

The paper aims to examine and evaluate the impact of the corporate life cycle on the financial performance of companies in developing countries. Profitability expressed as return on assets was used as the appropriate financial performance dummy. Leverage and corporate size expressed as operating profit were applied to refine the results of the analysis. The life cycle model by Dickinson (2011) was applied to determine the life cycle stage; the age variable was analysed to compare Dickinson non-sequential life cycle model with sequential ones. The data cover the financial indicators of 2019 of more than 9,000 companies from two emerging economies (Czech Republic and Slovakia). Two-way ANOVA was applied where one factor was one of the financial variables (profitability, leverage and size) and the age variable. Country was the second factor; the sub-objective was to examine the impact of the interaction between the country-level factor and the life-cycle factor on financial performance.

\section{Literature Review}

The corporate life cycle is one of the key aspects of management (Miller \& Friesen, 1984) as well as corporate finance (Anthony \& Ramesh, 1992; Damodaran, 2018 or Dickinson, 2011). The initial view of the corporate life cycle is based on product life cycle theory; the company is made up of various products. Unlike products, however, the company is also affected by other factors, so product life cycle methods are insufficient for the analysis of the business life cycle. Miller and Friesen (1984) note that life 
cycle stages differ due to changes in internal factors (managerial skills, financial resources and performance) and external factors (macroeconomic and competitive factors), which are largely based on the company's strategic decisions. Dickinson (2011) adds that the life cycle depends on the interaction of the company's strategy and the allocation of the company's resources.

Dickinson (2011) created one of the most widely used life cycle models based on different cash flow patterns over life cycle. Compared to other models, this fully non-sequential model is adaptable to different stages of the life cycle since cash flow patterns (different combinations of operating, investment and financial cash flow) absorb complex internal qualitative and quantitative factors together with external factors. It is also relevant for market capitalization and dividend analysis. Dickinson (2011) model contains 5 stages: Introduction, Growth, Maturity, Shake-out and Decline, each of these stages is expressed by a unique cash flow pattern.

The Introduction stage is characterized by negative working capital, a low level of collateral assets and associated low depreciation. Businesses face high corporate risk (both operational and credit) and cost of capital because they are largely financed by bank debt and only to a small extent by equity (Kramolis \& Dobes, 2020). There is a delay between revenue growth and profit growth (Yoo et al.., 2019), so the volatility and uncertainty of profit or cash flow is much higher for start-ups (Habib and Hasan, 2017), as well as the risk of bankruptcy is highest (Akbar et al., 2019). Hayn (1995) notes that small businesses report losses more often at this stage than large start-ups. Significant investment activity and profit uncertainty, together with growth in indebtedness, are reflected in negative operating cash flow, investment outflow and financial inflow.

Growing companies show growing revenues and reach a break-even point at this stage as the production capacity is growing (Zauskova et al., 2020). This reduces operational and bankruptcy risk (Akbar et al., 2019). It allows for higher debt ratios and long-term debt recovery, which contributes positively to profitability growth (Akbar, et al., 2020). However, profit still lags behind sales, operating cash flow is positive (Kort \& Wrzaczek, 2015) and the amount of internal resources is growing. Investment and financial activities have a similar course as in Introduction stage.

Mature companies are able to minimize their operating costs, which contributes to positive operating profit and cash flow. However, there is a difference between profit and cash flow because cash flow overtakes profit. Low level of investment activity means negative investment cash flow, Damodaran (2018) notes that mature enterprises have a much lower cost of debt, these companies are due to overall positive cash flow significantly funded the equity, dividends paid to shareholders and / or retain earnings. High liquidity and low working capital investments have a positive impact on profitability (Akbar et al. 2020) Revenue growth eliminates corporate risk.

The shake-out stage occurs when some companies with a lower market share leave the market and competition intensifies. Revenues are gradually declining along with corporate growth and stock prices (Miller \& Friesen, 1984). Therefore, companies are forced to innovate to stay in the market. Dickinson (2011) states that there is insufficient evidence in the literature on cash flow patterns of such companies. Businesses at this stage invest significantly to reverse the life cycle, as well as reduce business activities and increase investment cash flow. Habib and Hasan (2017) or Hussain et al. (2020) use this stage only as a benchmark for interpreting other stages of the life cycle. 
Declining companies usually have low production power, negative operating cash flow, low sales and profit. The risk of bankruptcy increases as the ability to repay debts by operating profit is reduced. The cost of capital also rises, but is lower than for start-ups (Gulec \& Karacaer, 2017). Edwards et al. (2016) state that low liquidity and financial distress at this stage can create space for tax avoidance practices.

Life cycle stages differ significantly in basic characteristics such as profitability, leverage, cash flow or liquidity. Current life cycle research addresses a wide range of financial aspects, and their research in emerging economies is broad. Akbar et al. (2020) state that business managers synchronize risk exposure with the corporate life cycle stage and excessive risk exposure of failing businesses can have a negative impact on financial performance. Faff et al. (2016) add to this that investment activities decrease during the life cycle, moreover, debt issuance has an increasing character in the Introduction and Growth stage, on the contrary, it decreases in other stages. Tian et al. (2015) agree with the development of debt over the life cycle; leverage is inverted $U$-shaped over the life cycle and cash flow patterns have a greater impact on capital structure than corporate age. Pinkova and Kaminkova (2012) report that the debt-to-equity ratio is similar at all stages of the life cycle except for Maturity, in which companies use more internal resources and retained earnings. Gulec and Karacaer (2017) add that their research on Turkish companies broadens the characteristics of companies at different stages of the life cycle: growing companies are riskier, mature companies bring higher returns. Declining companies are larger and more liquid than others. Start-ups have high R\&D cost volatility, which affects future profitability (Yoo et al., 2019). Mittal (2020) attributes the variability of R\&D to institutional factors. Michalkova (2021) focused on the quality of reported profits in the tourism industry; cash flow patterns play an important role in the context of earnings manipulations and they have an inverted U-shape during the life cycle. These results indicate that the life cycle affects not only the financial performance reported in the accounting figures, but also that expressed in cash flow. Profit analysis in Central European countries dealt with e.g. Kliestik, Valaskova et al. (2020), Siekelova et al. (2020) or Belas et al. (2020).

The research presented in this chapter points to the existing impact of the life cycle on the financial characteristics of a company, including financial performance. Profitability and leverage are inverted Ushaped as shown by the studies presented above. Nevertheless, these studies focus more on non-European emerging economies or listed companies. It is therefore important to examine whether the life cycle of a company has an impact on unlisted companies in emerging Central European economies. Based on previous hypotheses have been established:

H1: Business profitability varies over the life cycle in emerging Central European countries.

H2: Business leverage varies over the life cycle in emerging Central European countries.

\section{Research Method}

The paper aims to examine and evaluate the impact of the life cycle stage on corporate financial performance in emerging economies. A brief summary of previous research has shown that there are significant differences in financial factors over the life cycle, including financial performance indicators such as sales, cash flow and profit. The paper aims to examine and evaluate the impact of the life cycle stage on corporate financial performance in emerging economies. 
In addition to the impact of the life cycle, this study also focuses on the impact of country affiliation on financial performance. Emerging economies have many features in common, but there are differences in national tax, monetary and other macroeconomic policies, where we anticipate an impact on financial performance. The life cycle stage is assigned based on the Dickinson (2011) model, which determines the corresponding stage based on a combination of three types of cash flow (operational, investment and financial). There are a total of eight combinations of cash flow - cash flow patterns that correspond to the five stages of the life cycle (Introduction, Growth, Maturity, Shake-out and Decline). Cash flow patterns for each stage are shown in Table 1.

Table 1. Corporate life cycle and cash flow patterns according to Dickinson model

\begin{tabular}{ccccccccc}
\hline Cash flow & Introduction & Growth & Maturity & \multicolumn{3}{c}{ Shake-out } & \multicolumn{2}{c}{ Decline } \\
\hline Operating & Neg. & Pos. & Pos. & Neg. & Pos. & Neg. & Neg. & Neg. \\
Investing & Neg. & Neg. & Neg. & Neg. & Pos. & Pos. & Pos. & Pos. \\
Financing & Pos. & Pos. & Neg. & Neg. & Pos. & Neg. & Pos. & Neg. \\
\hline
\end{tabular}

Source: Author

Financial performance can be examined by several metrics as reported by Podhorska and Siekelova (2020). The return on assets was used to meet the objective of this study. Leverage is also analysed in connection with differences in capital structure and corporate tax policy. The third factor that affects overall business performance is the size of the business. In contrast to the classification of enterprises as small, medium and large, operating profit (EBIT) is used in this study. The advantage of this indicator is the differentiation of companies based on their operating performance. The last variable examined is the age of the enterprise; the aim of the survey is to determine whether the age of the enterprise plays a role in assigning a life cycle stage or not. All variables along with their formulas are shown in Table 2.

Table 2. Variables and their formula

\begin{tabular}{ccc}
\hline & & Variables \\
\hline Acronym & Name & Formula \\
\hline PROFI & Profitability & ROA $=\frac{\text { EAT }}{\text { Total assets }}$ \\
LEV & Leverage & Total leverage $=\frac{\text { long }- \text { term liabilities }+ \text { current liabilities }}{\text { Total assets }}$ \\
SIZE & Size & Size $=\ln ($ EBIT $)$ \\
AGE & Age of company & Company's agel \\
CYCLE & Life cycle stage & Life cycle stages according to Dickinson (2011) model \\
COUNTRY & Country dummy & Country affiliation (the Czech Republic, the Czech Republic)
\end{tabular}

Source: Author

The sample for this study was obtained in the Amadeus database, where three criteria were applied: a minimum value of total assets of 2,000,000 Euros, a turnover of more than 100,000 Euros in

\footnotetext{
${ }^{1}$ Difference between date of incorporation and date of firm year observation 
2019 and the company's registered office in the Czech Republic or Slovakia. 9,857 enterprises were selected as a gross sample and the financial data of these enterprises for 2019 were used.

Both qualitative factors (country and life cycle stage) are examined by a two-way ANOVA procedure. The advantage of this statistical method is the ability to analyse the impact of the interaction between two factors and to answer the question of whether there are significant differences between the levels of financial performance in different stages of the life cycle in different countries. As with the Oneway ANOVA, the Two-Way ANOVA has several assumptions such as normality of subsamples, case independence, homogeneity of variances, and no outliers. Assumptions are tested by suitable tests such as the Kolmogorov-Smirn test and the Levene's test. Wisorizing at $1 \%$ and $99 \%$ is used to remove outliers. A two-way ANOVA with robust standard errors is used if the assumptions are not met. The models listed in Eq. 1-4 show the regression forms of the Two-Way ANOVA for the four quantitative factors examined.

$$
\begin{aligned}
& \mathrm{PROFI}_{i}=\mu+\operatorname{COUNTRY_{j}}+C Y C L E_{k}+\operatorname{COUNTRY} \cdot C Y C L E_{j \cdot k}+\varepsilon_{i j k}
\end{aligned}
$$

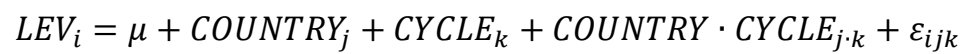

$$
\begin{aligned}
& \operatorname{SIZE}_{i}=\mu+\operatorname{COUNTRY_{j}}+\operatorname{CYCLE_{k}}+\operatorname{COUNTRY} \cdot C Y C L E_{j \cdot k}+\varepsilon_{i j k}
\end{aligned}
$$

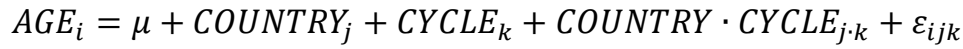

Where: $P R O F I_{i}$ - profitability, $L E V_{i}$ - leverage, $S I Z E_{i}$ - business size (operating profit), $A G E_{i}-$ business age, $i=1,2, \ldots, 9618$ - number of cases in net sample, $j=1,2$ - number of country $(1-$ the Czech Republic, 2 - Slovakia), COUNTRY $C Y C L E_{j \cdot k}$ - interaction term $(j \cdot k=1,2, \ldots, 10)$

\section{Results}

The first step in the financial performance analysis was to analyse the sample. The gross sample contained 9,857 enterprises and financial data for 2019. The missing data were present in the sample and therefore these enterprises were removed from the analysis. Subsequently, outliers were examined; the wisorizing method was used to $1 \%$ and $99 \%$. Maintaining sample size is an advantage of removing outliers' method. The net sample contained 9,618 companies. Descriptive statistic in Table 03 provides a closer look at the variables examined.

Table 3. Descriptive statistics of dependent variables according to COUNTRY and CYCLE factors

\begin{tabular}{cccccc}
\hline \multirow{2}{*}{ CYCLE } & Measure & \multicolumn{4}{c}{ Variable } \\
\cline { 3 - 5 } & & ROA & LEV & SIZE & AGE \\
\hline \multirow{2}{*}{ introduction } & Mean & 0,017 & 0,616 & 8,700 & 18,543 \\
& Std. Deviation & 0,064 & 0,294 & 1,783 & 7,846 \\
growth & Mean & 0,064 & 0,457 & 9,165 & 20,363 \\
& Std. Deviation & 0,070 & 0,272 & 1,601 & 7,780 \\
mature & Mean & 0,029 & 0,550 & 8,799 & 20,189 \\
& Std. Deviation & 0,086 & 0,286 & 1,666 & 8,317 \\
shake-out & Mean & 0,050 & 0,526 & 8,635 & 19,958 \\
& Std. Deviation & 0,087 & 0,292 & 1,699 & 8,144 \\
decline & Mean & 0,015 & 0,587 & 8,282 & 19,100 \\
& Std. Deviation & 0,083 & 0,322 & 1,845 & 8,505 \\
\hline
\end{tabular}




\begin{tabular}{cccccc}
\hline \multirow{2}{*}{ COUNTRY } & measure & ROA & LEV & SIZE & AGE \\
\hline \multirow{2}{*}{ Czech Republic } & Mean & 0,056 & 0,447 & 9,210 & 21,026 \\
& Std. Deviation & 0,084 & 0,275 & 1,688 & 7,739 \\
\multirow{2}{*}{ Slovakia } & Mean & 0,033 & 0,589 & 8,397 & 19,087 \\
& Std. Deviation & 0,081 & 0,292 & 1,644 & 8,340 \\
\hline
\end{tabular}

Source: Author

Financial performance measured by ROA indicates that growing companies have the highest return on assets, on average 5\%. On the contrary, mature enterprises achieve lower performance on average by almost half at $2.9 \%$. Start-ups and declining are about the same profitability (1.7\% vs. $1.5 \%)$. From the point of view of countries, there is a significant discrepancy; Czech companies achieve almost $6 \%$ return on assets compared to Slovak companies. In contrast, the debt of Slovak companies exceeds $50 \%$, which is a violation of the golden rule of risk compensation and speaks of a higher credit risk of these companies. Within the life cycle, Leverage copies the development of return on assets; where the least levered enterprises are in the growth stage, while start-ups and declining enterprises are the most indebted; as stated in the Literature review, the debt of start-ups is riskier as it is made up of rather shortterm riskier liabilities; moreover, the high indebtedness of declining companies is rather due to the accumulation of long-term liabilities. The size of the company representing the operating profit has a similar inverted U-shape as ROA and LEV, the difference arises in the peak point of the operating profit, which is on average the highest in growing companies. This indicates that the overall profitability of the company and the related indebtedness in the first stages of the life cycle is based more on operating activity. In mature enterprises, operating performance is declining, but the impact of investment and financial activity compensates for this decline. As can be seen from Table 3 above, the age structure of companies does not change significantly due to the change in cash flow patterns. This reveals that cash flow patterns are not dependent on the age of the business and the business moves dynamically from one stage to another without the need for a sequential process.

Descriptive statistics point to significant differences between variables within categories, but do not take into account the interaction between qualitative factors as Two-Way ANOVA does. Prior to its launch, the model's assumptions were verified. Kolmogorov-Smirn test at level of 0.05 has been made; together with histogram analysis he pointed to non-normality of subsamples. Secondly, Levene's test rejected the null hypothesis of homogeneity of variances. Standard Two-way ANOVA with violation of assumptions shows the incidence of type I error. Therefore, two-way ANOVA with robust standard errors is a suitable alternative. Summary ANOVA tables for all four dependent variables are given in Table 4.

Table 4. Summary Two-way Anova tables for dependent variables

\begin{tabular}{ccccccc}
\hline $\begin{array}{c}\text { dependent variable } \\
\text { Source }\end{array}$ & $\begin{array}{c}\text { Type III Sum of } \\
\text { Squares }\end{array}$ & df & $\begin{array}{c}\text { ROA } \\
\text { Mean } \\
\text { Square }\end{array}$ & F & Sig. & $\begin{array}{c}\text { Partial Eta } \\
\text { Squared }\end{array}$ \\
\hline Corrected Model & $3,867 \mathrm{a}$ & 9 & 0,43 & 65,647 & 0,000 & 0,058 \\
Intercept & 7,365 & 1 & 7,365 & 1125,206 & 0,000 & 0,105 \\
COUNTRY & 0,663 & 1 & 0,663 & 101,232 & 0,000 & 0,01 \\
CYCLE & 2,426 & 4 & 0,606 & 92,647 & 0,000 & 0,037 \\
\hline
\end{tabular}




\begin{tabular}{|c|c|c|c|c|c|c|}
\hline COUNTRY * CYCLE & 0,045 & 4 & 0,011 & 1,707 & 0,145 & 0,001 \\
\hline Error & 62,887 & 9608 & 0,007 & & & \\
\hline Total & 84,598 & 9618 & & & & \\
\hline Corrected Total & 66,754 & 9617 & & & & \\
\hline \multicolumn{7}{|c|}{ R Squared $=, 058($ Adjusted R Squared $=, 057)$} \\
\hline dependent variable & & & $\mathbf{L E}$ & & & \\
\hline Source & $\begin{array}{c}\text { Type III Sum of } \\
\text { Squares }\end{array}$ & df & $\begin{array}{c}\text { Mean } \\
\text { Square } \\
\end{array}$ & $\mathbf{F}$ & Sig. & $\begin{array}{c}\text { Partial Eta } \\
\text { Squared }\end{array}$ \\
\hline Corrected Model & $64,907 a$ & 9 & 7,212 & 90,919 & 0,000 & 0,078 \\
\hline Intercept & 1621,777 & 1 & 1621,777 & 20445,46 & 0,000 & 0,68 \\
\hline COUNTRY & 29,071 & 1 & 29,071 & 366,491 & 0,000 & 0,037 \\
\hline CYCLE & 15,544 & 4 & 3,886 & 48,989 & 0,000 & 0,02 \\
\hline COUNTRY $*$ CYCLE & 0,933 & 4 & 0,233 & 2,942 & 0,019 & 0,001 \\
\hline Error & 762,127 & 9608 & 0,079 & & & \\
\hline Total & 3494,546 & 9618 & & & & \\
\hline Corrected Total & 827,034 & 9617 & & & & \\
\hline \multicolumn{7}{|c|}{ R Squared $=, 078($ Adjusted R Squared $=, 078)$} \\
\hline dependent variable & & & SIZ & & & \\
\hline Source & $\begin{array}{c}\text { Type III Sum of } \\
\text { Squares }\end{array}$ & df & $\begin{array}{c}\text { Mean } \\
\text { Square } \\
\end{array}$ & $\mathbf{F}$ & Sig. & $\begin{array}{c}\text { Partial Eta } \\
\text { Squared }\end{array}$ \\
\hline Corrected Model & $2233,975 a$ & 9 & 248,219 & 91,991 & 0,000 & 0,079 \\
\hline Intercept & 430831,7 & 1 & 430831,7 & 159668,5 & 0,000 & 0,943 \\
\hline COUNTRY & 909,81 & 1 & 909,81 & 337,18 & 0,000 & 0,034 \\
\hline CYCLE & 573,039 & 4 & 143,26 & 53,093 & 0,000 & 0,022 \\
\hline COUNTRY $*$ CYCLE & 78,529 & 4 & 19,632 & 7,276 & 0,000 & 0,003 \\
\hline Error & 25925,16 & 9608 & 2,698 & & & \\
\hline Total & 765130,6 & 9618 & & & & \\
\hline Corrected Total & 28159,13 & 9617 & & & & \\
\hline \multicolumn{7}{|c|}{ R Squared $=, 079($ Adjusted R Squared $=, 078)$} \\
\hline dependent variable & \multicolumn{6}{|c|}{ AGE } \\
\hline Source & $\begin{array}{l}\text { Type III Sum of } \\
\text { Squares }\end{array}$ & df & $\begin{array}{l}\text { Mean } \\
\text { Square }\end{array}$ & $\mathbf{F}$ & Sig. & $\begin{array}{c}\text { Partial Eta } \\
\text { Squared }\end{array}$ \\
\hline Corrected Model & $11175,990 \mathrm{a}$ & 9 & 1241,777 & 19,065 & 0,000 & 0,018 \\
\hline Intercept & 2181565 & 1 & 2181565 & 33492,82 & 0,000 & 0,777 \\
\hline COUNTRY & 4379,81 & 1 & 4379,81 & 67,242 & 0,000 & 0,007 \\
\hline CYCLE & 2017,311 & 4 & 504,328 & 7,743 & 0,000 & 0,003 \\
\hline COUNTRY $*$ CYCLE & 230,65 & 4 & 57,663 & 0,885 & 0,472 & 0 \\
\hline Error & 625819,8 & 9608 & 65,135 & & & \\
\hline Total & 4460174 & 9618 & & & & \\
\hline Corrected Total & 636995,8 & 9617 & & & & \\
\hline \multicolumn{7}{|c|}{ R Squared $=, 018($ Adjusted R Squared $=, 017)$} \\
\hline
\end{tabular}

Source: Author

The results of the models indicate that the life cycle of the company has a significant impact on the financial performance of companies in terms of their overall profitability, as well as operating profit representing the size of the company. Based on this, hypothesis H1 is confirmed. The interaction between macroeconomic and competitive factors (COUNTRY variable) and the life cycle is significant only for Leverage and Size. This means that the financial performance of Slovak and Czech companies depends on the life cycle stage and economic environment of the business country, but their impact is not related. 
In the case of operating profit (SIZE) and leverage (LEV), there is an interaction between the factors examined; partial eta squared points out that the interaction factor explains only a small part of the variability of LEV and SIZE; only $0.1 \%$ and $0.3 \%$, respectively. This weak interaction suggests that the COUNTRY factor has a greater impact on the variability of leverage and operating profit than the life cycle, which means that the hypothesis $\mathrm{H} 2$ is rejected. Differences in average Leverage and operating profit occur within countries only at certain stages of the life cycle.

Table 4 shows that a company's life cycle has a significant impact on financial performance in emerging Central European economies. The last step of the analysis is to investigate the main and simple main effects. In the case of Profitability and Age, the interaction is insignificant and therefore CYCLE was analysed as the main effect. The simple main effects examine the influence of one factor within a subset of the other factor, which was applied to the variables LEVERAGE and SIZE. The post hoc results for the dependent variables are shown in Table 05.

Table 5. Summary of results of post hoc tests (main and simple main effects) for CYCLE factor

\begin{tabular}{ccccccc}
\hline $\begin{array}{c}\text { Variable } \\
\text { significant difference (post } \\
\text { hoc tests) }\end{array}$ & ROA & $\begin{array}{c}\text { LEV } \\
\text { the Czech } \\
\text { Republic }\end{array}$ & $\begin{array}{c}\text { Slovakia } \\
\text { the Czech } \\
\text { Republic }\end{array}$ & Slovakia & AGE \\
\hline introduction - growth & H1 & H1 & H1 & H0 & H1 & H1 \\
introduction - mature & H0 & H0 & H1 & H0 & H0 & H1 \\
introduction - shake-out & H1 & H1 & H1 & H0 & H0 & H1 \\
introduction - decline & H0 & H0 & H0 & H0 & H1 & H0 \\
growth - mature & H1 & H1 & H1 & H0 & H1 & H0 \\
growth - shake-out & H1 & H1 & H1 & H1 & H1 & H0 \\
growth - decline & H1 & H1 & H1 & H1 & H1 & H1 \\
mature - shake-out & H1 & H0 & H0 & H1 & H0 & H0 \\
mature - decline & H1 & H0 & H1 & H1 & H1 & H1 \\
shake-out - decline & H1 & H0 & H1 & H0 & H1 & H0 \\
\hline
\end{tabular}

Source: Author

Return on assets shows significant differences between stages of the corporate life cycle, confirming the results of the descriptive statistics in Table 3; Slovak and Czech companies achieve the highest performance in Growth stage, and subsequently the financial performance has a declining tendency. The age variable also confirmed the assumptions based on the analysis of average values; growing businesses are significantly older than start-ups, while mature and shake-out businesses are about the same age. A comparison of operating cash flow in individual stages and age of companies shows that companies with operating inflow / outflow have a similar age. Conversely, enterprises in the stage with operational inflow differ significantly in age compared to enterprises in the stage with operational outflow. These results indicate that start-ups, shake-outs and declining companies are subject to a higher operational risk due to a lack of internal resources, and this risk is associated on average with younger companies than for growing and mature companies.

The variable Leverage confirms the assumptions resulting from the analysis of descriptive statistics. In both countries, Leverage is higher in the Introduction and Decline stages, but in the Czech 
Republic the development of Leverage is milder during the life cycle as documented by the insignificant difference between leverage of start-ups and mature enterprises as well as mature and declining enterprises. In terms of operating profit (SIZE), it is clear that Czech companies in the first three stages of the life cycle have, on average, a similar ability to generate operating profit. Subsequently, operating profit decreases significantly as documented by significant differences between the Growth stage and subsequent stages. However, Slovak companies report different results, the development of this indicator is more volatile during the life cycle.

The results of ANOVA tests, together with the post hoc tests, show a significant impact of the life cycle on financial performance and therefore the corporate life cycle should play a key role in determining the financial strategy of companies in emerging Central European economies.

\section{Conclusion and Discussion}

The results presented in the previous chapter indicate that overall profitability as well as leverage mimic the inverted U-shape similar to that reported by Akbar et al. (2019), Hussain et al. (2020) or Tian et al. (2015). However, Czech and Slovak companies achieve the highest performance in the growth stage and the lowest leverage in the growth stage, in contrast to the above-mentioned studies. As a result, compared to theoretical models and empirical results from other developing countries, peak financial performance is very fast. Damodaran (2018) states that the compressed life cycle is typical of technical sectors and that a sharp increase in profitability after reaching a peak is followed by a sharp decline. These statements agree with the obtained results and the structure of the Slovak and Czech business sector, which is dominated by industrial enterprises.

The age of the company in the life cycle does not have as significant an effect as in the sequential models by Anthony and Ramesh (1992) or Liu (2006). This provides evidence that cash flow patterns do not depend on the age of the business; Negative operating cash flows are achieved by companies in a similar age group, regardless of the economy in which the company is located in the developing economy. Michalkova (2021) also found a similar connection between the negative operating cash flow and the quality of profit in Central European countries.

The findings of this study provide several valuable elements in investor decision-making and corporate policy-making. First of all, companies in the developing Czech and Slovak economies are rapidly achieving the highest overall and operational profitability as well as the lowest leverage already in the growth stage, which indicates the stabilization of the company's market position. This gives shareholders the opportunity to demand the payment of dividends in Central European companies rather than in companies in developed economies. On the other hand, company managers should reflect on the rapid achievement of a stable position of the company and the possible requirements of shareholders for dividends in terms of creating sufficient internal resources. In terms of capital structure, it should be noted that achieving a stable position in the Growth stage carries with it the possibility of increasing credit risk in the future life of the company. Therefore, it is necessary to take into account the relationship between profitability and credit risk / leverage when creating a debt policy strategy. Second, the stages of the life cycle are represented by cash flow patterns that, as shown by the results of the study, are not directly tied to the age of the business. Therefore, investors should not associate the stability of the company with 
older age but with a suitable cash flow structure. Moreover, the Dickinson model is a non-sequential model, which implies that the stages of the life cycle change dynamically along with cash flow and the stability of the company is expressed in the stable structure of positive cash flow associated with high financial performance.

In conclusion, this study provides a closer look at financial performance, and therefore future research focusing on a wider range of financial indicators such as liquidity, tangibility or dividend yield may shed light on the complexity of the life cycle phenomenon in financial performance and strategy.

\section{Acknowledgments}

The paper is an output of the scientific project VEGA 1/0210/19: Research of innovative attributes of quantitative and qualitative fundaments of the opportunistic earnings modelling.

\section{References}

Akbar, A., Akbar, M., Tang, W., \& Qureshi, M. A. (2019). Is Bankruptcy Risk Tied to Corporate LifeCycle? Evidence from Pakistan. Sustainability, 11(3), 678. https://doi.org/10.3390/su11030678

Akbar, M., Akbar, A., Maresova, P., Yang, M., \& Arshad, H. M. (2020). Unraveling the Bankruptcy Risk-Return Paradox across the Corporate Life Cycle. Sustainbility, 12(9), 3547. https://doi.org/10.3390/su12093547

Anthony, J. H., \& Ramesh, K. (1992). Association between accounting performance measures and stock prices: A test of the life cycle hypothesis. Journal of Accounting and Economics, 15(2), 203 - 227. https://doi.org/10.1016/0165-4101(92)90018-W

Belas, J., Amoah, J., Petrakova, Z., Kliuchnikava, Y., \& Bilan, Y. (2020). Selected Factors of SMEs Management in the Service Sector. Journal of Tourism and Services, 21(11), 129-146. https://doi.org/10.29036/jots.v11i21.215

Damodaran, A. (2018). The corporate life cycle: growing up is hard to do! People. Stern. http://people.stern.nyu.edu/adamodar/pdfiles/country/corporatelifecycleLongX.pdf

Dickinson, V. (2011). Cash Flow Patterns as a Proxy for Firm Life Cycle. The Accounting Review, 86(6), 1969 - 1994. https://doi.org/10.2308/accr-10130

Edwards, A., Schwab, C., \& Shevlin, T. (2016). Financial constraints and cash tax savings. The Accounting Review, 91(3), 859-881. https://doi.org/10.2308/accr-51282

Faff, R., Kwok, W. C., Podolski, E. J., \& Wong, G. (2016). Do corporate policies follow a life-cycle? Journal of Banking \& Finance, 69, 95-107. https://doi.org/10.1016/j.jbankfin.2016.04.009

Gulec, O. F., \& Karacaer, S. (2017). Corporate life cycle methods in emerging markets: evidence from Turkey. Journal of Economics, Finance \& Accounting, 4(3), 224 - 236. https://doi.org/10.17261/Pressacademia.2017.690

Habib, A., \& Hasan, M. M. (2017). Firm life cycle, corporate risk-taking and investor sentiment. Accounting \& Finance, 57(2), 456 - 497. https://doi.org/10.1111/acfi.12141

Hayn, C. (1995). The information content of losses. Journal of Accounting and Economics, 20(2), 125 153. https://doi.org/10.1016/0165-4101(95)00397-2

Hussain, A., Akbar, M., Khan, M. K., Akbar, A., Panait, M., \& Voica, M.C. (2020). When Does Earnings Management Matter? Evidence across the Corporate Life Cycle for Non-Financial Chinese Listed Companies. Journal of Risk and Financial Management, 13(12), 313. https://doi.org/10.3390/jrfm13120313

Kliestik, T., Nica, E., Musa, H., Poliak, M., \& Mihai, E. A. (2020). Networked, Smart, and Responsive Devices in Industry 4.0 Manufacturing Systems. Economics, Management, and Financial Markets, 15(3), 23-29. https://doi.org/10.22381/EMFM15320203 
Kliestik, T., Valaskova, K., Nica, E., Kovacova, M., \& Lazaroiu, G. (2020). Advanced methods of earnings management: monotonic trends and change-points under spotlight in the Visegrad countries. Oeconomia Copernicana, 11(2), 371-400. https://doi.org/10.24136/oc.2020.016

Konecny, Z., \& Zinecker, M. (2016). Optimizing Risk Structure in Connection with the Corporate Life Cycle and Sector Cyclicity. Acta Universitatis Agriculturae et Silviculturae Mendelianae Brunensis, 64, 949-959. https://doi.org/10.11118/actaun201664030949

Kort, P. M., \& Wrzaczek, S. (2015). Optimal firm growth under the threat of entry. European Journal of Operational Research, 246(1), 281-292. https://doi.org/10.1016/j.ejor.2015.04.030

Kramolis, J., \& Dobes, K. (2020). Debt as a financial risk factor in SMEs in the Czech Republic. Equilibrium. Quarterly Journal of Economics and Economic Policy, 15(1), 87-105. https://doi.org/10.24136/eq.2020.005

Liu, M. (2006). Accruals and Managerial Operating Decisions Over the Firm Life cycle (Doctoral dissertation, Massachusetts Institute of Technology). Retrieved from http://oastats.mit.edu/bitstream/handle/1721.1/37251/85835990MIT.pdf? sequence $=2 \&$ isAllowed $=\mathrm{y}$

Metzker, Z., \& Zvarikova, K. (2021). The Perception of Company Employees by SMEs with CSR Concept Implementation. International Journal of Entrepreneurial Knowledge, 9(1), 81-96. https://doi.org/10.37335/ijek.v9i1.128

Michalkova, L. (2021). Earnings quality and accruals over company's life cycle. SHS Web of Conferences, 92, 02043. https://doi.org/10.1051/shsconf/20219202043

Miller, D., \& Friesen, P. H. (1984). A Longitudinal Study of the Corporate Life Cycle. Management Science, 30(10), 1161-1183. https://doi.org/10.1287/mnsc.30.10.1161

Mittal, H. (2020). How does the institutional context of an emerging economy shape the innovation trajectory of different types of firms? A case study of India. Ekonomicko-manazerske spektrum, 14(2), 36-51. https://doi.org/10.26552/ems.2020.2.36-51

Pinkova, P., \& Kaminkova, P. (2012). Corporate life cycle as determinant of capital structure in companies of Czech automotive industry. Acta Universitatis Agriculturae et Silviculturae Mendelianae Brunensis, 60(2), 255-259. https://doi.org/10.11118/actaun201260020255

Podhorska, I., \& Siekelova, A. (2020). Enterprises Financial Performance in a Globalized World. SHS Web of Conferences. 74, 05018. https://doi.org/10.1051/shsconf/20207405018

Riley, C., Vrbka, J., \& Rowland, Z. (2021). Internet of Things-enabled Sustainability, Big Data-driven Decision-Making Processes, and Digitized Mass Production in Industry 4.0-based Manufacturing Systems. Journal of Self-Governance and Management Economics, 9(1), 42-52. https://doi.org/10.22381/jsme9120214

Siekelova, A., Androniceanu, A., Durana, P., \& Michalikova Frajtova, K. (2020). Earnings Management (EM), initiatives and company size: an empirical study. Acta Polytechnica Hungarica, 17(9), 4156. https://doi.org/10.12700/APH.17.9.2020.9.3

Tian, L., Han, L., \& Zhang, S. (2015). Business Life Cycle and Capital Structure: Evidence from Chinese Manufacturing Firms. China \& World Economy, 23(2), 22-39. https://doi.org/10.1111/cwe.12105

Yoo, J., Lee, S., \& Park, S. (2019). The Effect of Firm Life Cycle on the Relationship between R\&D Expenditures and Future Performance, Earnings Uncertainty, and Sustainable Growth. Sustainability, 11(8), 2371. https://doi.org/10.3390/su11082371

Zauskova, A., Lyakina, M., Tretyak, V., \& Miklencicova, R. (2020). Application of artificial neural networks to cost factors stimulating innovation - The case of Slovakia. Ekonomicko-manazerske spektrum, 14(1), 97-105. https://doi.org/10.26552/ems.2020.1.97-105 